\section{EREM 77/3}

Journal of Environmental Research, Engineering and Management

Vol. 77 / No. 3 / 2021

pp. 66-73

DOI 10.5755/j01.erem.77.3.28928

\section{On Implementation of Plants in the Indoor Environment in Intelligent Buildings}

\begin{tabular}{l|l} 
Received 2021/04 & Accepted after revision 2021/07
\end{tabular}

\title{
On Implementation of Plants in the Indoor Environment in Intelligent Buildings
}

\section{Ondřej Franek*, Čeněk Jarský}

Department of Construction Technology, Faculty of Civil Engineering, Czech Technical University in Prague, Thákurova 2077/7, Prague 16629, Czech Republic

*Corresponding author: ondrej.franek@fsv.cvut.cz

The article deals with the research of the influence of plants on the potential energy savings in the field of ventilation of intelligent buildings. It is known that selected plants can effectively reduce the concentration of carbon dioxide even in the indoor environment of buildings in poor lighting conditions. The paper presents a theoretical simulation method that shows the potential of selected plants to reduce the concentration of carbon dioxide in the indoor environment and thus reduce the requirement for the amount of supplied air in intelligent buildings which are air-conditioned based on the current and required concentration of carbon dioxide. The results of the research are very influential; in terms of overall percentage savings, plants have the most significant effect in buildings with lower indoor air quality (IDA4+), while they have a less significant effect in areas with high air quality according to carbon dioxide concentration (IDA2, IDA3). Research with the help of computer simulation shows that the implementation of $1 \mathrm{~m}^{2}$ of living green plants, depending on the quality class of the IDA indoor environment, can bring savings on the amount of supplied air in the range of $0.058 \%$ to $1.997 \%$ for a typical office for 4 people.

Keywords: carbon dioxide, indoor environment, air comfort, indoor greening, climate change. 


\section{Introduction}

The quality of the building's indoor environment from the point of view of the air quality indicator has become very topical nowadays. While there is an increasing interest in the energy efficiency of modern intelligent buildings, monitoring the quality of the indoor environment in a practical environment is not given the necessary importance. To ensure an appropriate indoor air quality level, the building must be sufficiently ventilated or air-conditioned. Most intelligent buildings have controlled ventilation based on the current concentration of $\mathrm{CO}_{2}$ in the indoor environment. In general, the indoor environment can be divided into 4 basic groups of IDA (indoor air) according to the quality of the indoor environment.

In order to adjust the supply air to the required temperature, a big amount of energy is necessary, and it is assumed that even minimal savings can have a great importance from a global perspective (Ürge-Vorsatz et al., 2015). If the concentration of carbon dioxide in outdoor air increases in the coming decades from the current value from $410 \mathrm{ppm}$ to the predicted $670 \mathrm{ppm}$ in the year 2100 (Hersoug et al., 2012; McNeil \& Sasse, 2016; Field et al., 2014), the problem of building ventilation is becoming very important. In recent years, intensive research on the implementation of plants in the indoor environment of intelligent buildings with respect to the internal parameters of a typical environment has begun. It has been found that selected plant species can effectively reduce $\mathrm{CO}_{2}$ in indoor conditions (Gubb et al., 2018; Tudiwer $\&$ Korjenic, 2017; Shao et al., 2021) and thus contribute to improving the quality of the indoor environment and at the same time reducing the amount of air supplied, thus bringing energy savings for building ventilation.

\section{Methods}

\section{Description of the current state}

The basic indicator of the quality of the indoor environment is the concentration of $\mathrm{CO}_{2}$. The generally recommended maximum $\mathrm{CO}_{2}$ concentration is 1000 ppm (Torpy et al., 2017; Lu et al., 2015; Tsai et al., 2012; Seppanen et al., 1999). Higher concentrations can have a negative effect on the people's performance in the indoor environment of buildings (Satish et al., 2012; Allen et al., 2016; Pinto et al., 2021; Chan et al., 2020). The sick building syndrome can appear in places with long-term occurrence in environments with higher concentrations of $\mathrm{CO}_{2}$. To maintain the concentration of $\mathrm{CO}_{2}$ in the indoor environment at the required values, it is necessary to ventilate the environment sufficiently. It is known that energy consumption for indoor air conditioning, i.e., energy consumed for heating and cooling, represents on average 40 $\%$ of the total energy consumption for the operation of office buildings per year (Ürge-Vorsatz et al., 2015; Serrano et al., 2017). Considering that, if the $\mathrm{CO}_{2}$ concentration in the supply air continues to increase (Hersoug et al., 2012; McNeil \& Sasse, 2016), it is important to look for alternative methods to ensure the required indoor air quality.

Several studies have demonstrated that the selected plants can be effective reducers of carbon dioxide, even under conditions corresponding to the internal environment (Gubb et al., 2018; Franek et al., 2020; Pettit et al., 2017; Irga et al., 2019). Between such plants belong, for example, Hedera helix, Spathiphyllum wallisii 'Bellini', Spathiphyllum wallisii 'Verdi'. One of the most important aspects for the photosynthetic response of plants is a sufficient photosynthetic photon flux density (PPFD). In an indoor environment, PPFD less than $10 \mu \mathrm{mol} / \mathrm{m}^{2} / \mathrm{s}$ can be considered as low-level lighting, while PPFD values around $50 \mu \mathrm{mol} / \mathrm{m}^{2} / \mathrm{s}$ can be considered as high-level lighting.

Using light sources in indoor environments can lead to very high levels of illumination in a range greater than $200 \mu \mathrm{mol} / \mathrm{m}^{2} / \mathrm{s}$. At lighting values lower than $10 \mu \mathrm{mol} /$ $\mathrm{m}^{2} / \mathrm{s}$, plants can assimilate $\mathrm{CO}_{2}$ only to a limited extent, especially selected plants such as Spathiphyllum wallisii 'Verdi' (Gubb et al., 2018; Pennisi \& van lersel, 2012). At values around $50 \mu \mathrm{mol} / \mathrm{m}^{2} / \mathrm{s}$, they can already effectively assimilate $\mathrm{CO}_{2}$, for example plants such as: Hedera helix, Spathiphyllum wallisii 'Bellini', Spathiphyllum wallisii 'Verdi' (Gubb et al., 2018). In case of a further requirement for a higher ability to assimilate $\mathrm{CO}_{2}$ by plants, it is appropriate to install artificial lighting in the indoor 
environment to ensure a higher and constant PPFD ( Nelson et al., 2014). The assimilation of these selected plants slightly influenced by the humidity of the substrate. The $\mathrm{CO}_{2}$ assimilation rate of selected plants for lighting conditions of $50 \mu \mathrm{mol} / \mathrm{m}^{2} / \mathrm{s}$ is shown in Table 1.

Table 1 shows that selected 3 cultivars can assimilate $\mathrm{CO}_{2}$ even under the light conditions of the indoor environment of buildings, specifically at PPFD $50 \mathrm{\mu mol} /$ $\mathrm{m}^{2} / \mathrm{s}$ is the most effective plant from the selected cultivars is Spathiphyllum wallissii 'Verdi', which is able to assimilate $0.110 \mathrm{~g} / \mathrm{h} / \mathrm{m}^{2}$, Spathiphyllum wallisii 'Bellini' $0.066 \mathrm{~g} / \mathrm{h} / \mathrm{m}^{2}$ and Hedera helix $0.062 \mathrm{~g} / \mathrm{h} / \mathrm{m}^{2}$. At
PPFD $200 \mu \mathrm{mol} / \mathrm{m}^{2} / \mathrm{s}$, the most effective Hedera helix with an assimilation capacity of $0.998 \mathrm{~g} / \mathrm{h} / \mathrm{m}^{2}$. The values are characteristic for an ambient temperature of $25^{\circ} \mathrm{C}$, a relative humidity in the range of $35-45 \%$ and a $\mathrm{CO}_{2}$ concentration in the environment in the range of 400-450 ppm. It is important to point out that in general the increasing concentration of $\mathrm{CO}_{2}$ in the indoor environment increases the ability of plants to assimilate $\mathrm{CO}_{2}$ up to several times. However, this involves a much higher amount of light, and in this modeling, this effect is, therefore, neglected due to the relatively low level of illumination in the model's indoor environment.

Table 1. $\mathrm{CO}_{2}$ assimilation by selected plants according to the PPFD level (Gubb et al., 2018)

\begin{tabular}{|c|c|c|c|c|}
\hline \multirow{2}{*}{ Cultivar } & \multirow{2}{*}{$\mathrm{LCP}\left[\mu \mathrm{mol} / \mathrm{m}^{2} / \mathrm{s}\right]$} & \multirow{2}{*}{ Cultivar metabolism } & \multicolumn{2}{|c|}{ Net $\mathrm{CO}_{2}$ assimilation per $\mathrm{m}^{2}$ of plant's leaf $\left[\mathrm{g} / \mathrm{h} / \mathrm{m}^{2}\right]$} \\
\hline & & & PPFD 50 & PPFD 200 \\
\hline Hedera helix & 30.9 & $\mathrm{C} 3$ & 0.062 & 0.998 \\
\hline Sp.w. Bellini & 31.9 & $\mathrm{C} 3$ & 0.066 & 0.316 \\
\hline Sp. w. Verdi & 20.1 & C3 & 0.110 & 0.325 \\
\hline
\end{tabular}

For optimal implementation of this new experimental method into the indoor environment of buildings, it is appropriate to incorporate the conceptual solution of the method, including preliminary calculations into the design of newly prepared projects of intelligent buildings before construction to eliminate the possible shortcomings of the design itself, which take into account a spatial arrangement and furniture in the indoor environment, effect of sunlight and overall urbanism of the site (Tuháček et al., 2020; Hormigos-Jimenez et al., 2018; Buratti et al., 2017; Liu et al., 2019; Hormigos-Jimenez et al., 2018; Aryal \& Leephakpreeda, 2015). The indoor environment of buildings is polluted from the point of view of $\mathrm{CO}_{2}$ mainly by human activity, while the administrative worker produces on average $31.5 \mathrm{~g} / \mathrm{h} /$ person of $\mathrm{CO}_{2}$ in the office environment (Persily \& de Jonge, 2017).

\section{Methodology description and input data}

Based on a defined model of the indoor environment, the potential of implementing plants in the indoor environment of buildings for $\mathrm{CO}_{2}$ assimilation is researched, and by what percentage less air can be supplied with a certain amount of green leaf area of selected cultivars, if the building is ventilated according to measurement with a current $\mathrm{CO}_{2}$ concentration sensor. The model environment examines the efficiency of plants under light conditions of PPFD $50 \mu \mathrm{mol} / \mathrm{m}^{2} / \mathrm{s}$ and PPFD $200 \mu \mathrm{mol} / \mathrm{m}^{2} / \mathrm{s}$, in combination for individual indoor air quality classes IDA2, IDA3, IDA4 and IDA4 +.

The model environment is an office for 4 administrative workers with a total volume of $71.8 \mathrm{~m}^{3}$, considering the planting of $1 \mathrm{~m}^{2}$ of green leaves of the plant per 1 worker. The model case considers the start of working hours with the initial concentration of $\mathrm{CO}_{2}$ at the value of the maximum permissible concentration according to the specified individual IDA classes. Specifically, there are 4 IDA classes, each with a maximum allowable concentration of $\mathrm{CO}_{2}$ in the indoor environment as follows: IDA2 max 600 ppm; IDA3 max 1000 ppm; IDA4 also allows concentrations higher than 1000 ppm. For class IDA4, the maximum concentration is determined by this research at 1400 ppm (IDA4) and at 2000 ppm (IDA4+). The IDA 1 class was in this modeling omitted, because the office environment is usually not required to meet such a high-quality class of the indoor environment. The IDA1 class is typically used in very clean environments, 
such as operating rooms and laboratories. The concentration of $\mathrm{CO}_{2}$ in the supply air is considered to be $410 \mathrm{ppm}$, and the effect of air mixing in the ventilation system can be neglected, because in the case of mixing with circulating air, it is necessary to supply a relatively larger amount of air to bring the indoor environment to the required IDA class. The $\mathrm{CO}_{2}$ production of each worker is $31.5 \mathrm{~g} / \mathrm{h} /$ person. The reduction of $\mathrm{CO}_{2}$ by plants for PPFD $50 \mu \mathrm{mol} / \mathrm{m}^{2} / \mathrm{s}$ is considered to be $0.11 \mathrm{~g} / \mathrm{h} / \mathrm{m}^{2}$, and for PPFD $200 \mu \mathrm{mol} / \mathrm{m}^{2} / \mathrm{s}, 0.998 \mathrm{~g} / \mathrm{h} /$ $\mathrm{m}^{2}$ is considered. The modeling (simulation) neglects the effect of changes in plant temperature. In an office environment it can be considered a stable temperature in the range 19 to $25^{\circ} \mathrm{C}$. It is neglected the influence of relative humidity which is in an indoor environment in a range from 35 to $55 \%$, and neglects the change in atmospheric pressure, which is determined on the present research at value of $101.325 \mathrm{kPa}$. For the conversion of ppm values to mass concentration, the molar mass of $\mathrm{CO}_{2}$ is $44.009 \mathrm{~g} / \mathrm{mol}$. Within the modeling (simulation) capability is further neglected higher $\mathrm{CO}_{2}$ assimilation by plants in areas with higher concentrations of $\mathrm{CO}_{2}$, as is foreseen with the illumination level of the external environment, i.e., PPFD $>1200 \mathrm{umol} / \mathrm{m}^{2} / \mathrm{s}$, which is a prerequisite for higher $\mathrm{CO}_{2}$ assimilation. The effect of mixing plant-treated air with extracted air is neglected.

\section{Computational models}

In the model example, it is necessary to take into account the initial state of $\mathrm{CO}_{2}$ concentration in the indoor environment, $\mathrm{CO}_{2}$ production during human activity, $\mathrm{CO}_{2}$ reduction during air exchange from the outside environment, $\mathrm{CO}_{2}$ loss due to implementation of experimental method, location of green plants. For these purposes, the following formulas were defined in the research report (1):

$$
C_{\text {in }}=\frac{m_{\text {ori }}+m_{\text {pro }}-m_{\text {red }}}{V_{\text {in }}}
$$

Where: $C_{i n}$ - is the instantaneous indoor pollutant concentration $\left[\mathrm{g} / \mathrm{m}^{3}\right] ; m_{\text {ori }}$ - is the initial indoor pollutant mass [g]; $m_{\text {pro }}$ - is the indoor pollutant mass excess [g]; $m_{\text {red }}$ - is the indoor pollutant mass loss [g]; $V_{\text {in }}$ - is the total volume of indoor air $\left[\mathrm{m}^{3}\right]$.

The requirement for the amount of supply air in relation to the required concentration is based on (2):

$$
Q_{s a}=\frac{V_{i n} \cdot\left(C_{r e q}-C_{i n}\right)}{\left(C_{o u t}-C_{i n}\right)}
$$

Where: $Q_{s a}$ - is the requirement for the amount of supply air for office in a defined period of time of 1 hour $\left[\mathrm{m}^{3} /\right.$ $\left.\mathrm{h}^{1}\right] ; V_{\text {in }}$ - is the total volume of indoor air $\left[\mathrm{m}^{3}\right] ; C_{\text {req }}-$ is the desired pollutant concentration $\left[\mathrm{g} / \mathrm{m}^{3}\right] ; C_{\text {in }}$ - is the current pollutant concentration inside the room area $\left[\mathrm{g} / \mathrm{m}^{3}\right] ; \mathrm{C}_{\text {out }}{ }^{-}$ is the pollutant concentration of the supplied air $\left[\mathrm{g} / \mathrm{m}^{3}\right]$.

\section{Results and Discussion}

Based on the above defined formulas, it was found that plants in the indoor environment of buildings that were ventilated (air-conditioned) according to the current concentration of $\mathrm{CO}_{2}$ could achieve operational savings in terms of demands on the amount of air supplied. According to the assumption, it was shown that under very low PPFD lighting conditions of $50 \mu \mathrm{mol} / \mathrm{m}^{2} / \mathrm{s}$ of the indoor environment, the plants assimilate $\mathrm{CO}_{2}$ and thus reduce the air supply requirement. A more significant energy saving requirement is achieved with lighting in PPFD values of $200 \mu \mathrm{mol} / \mathrm{m}^{2} / \mathrm{s}$. The results of the model are shown in Table 2.

Table 2. Modeling results according to PPFD levels and according to IDA class

\begin{tabular}{c|c|c|c}
\multirow{2}{*}{ Class IDA } & \multicolumn{3}{|c}{ Rate of ventilation air flow for office [m $3 / \mathrm{h}]$} \\
\cline { 2 - 4 } & Without plants & With plants and PPFD 50 & With plants and PPFD 200 \\
\hline IDA2 & 59.96 & 59.93 & 59.64 \\
\hline IDA3 & 44.51 & 44.45 & 43.97 \\
\hline IDA4 & 35.39 & 35.33 & 34.82 \\
\hline IDA4+ & 27.07 & 27.01 & 26.53 \\
\hline
\end{tabular}


Table 2 shows that the lowest effect of plants was observed for IDA2 under PPFD illumination of $50 \mathrm{\mu mol} /$ $\mathrm{m}^{2} / \mathrm{s}$, where plants for the model environment had the effect of reducing the supply air requirement by only $0.05 \%$. The greatest effect of plants was observed with IDA4+ under PPFD lighting of $200 \mu \mathrm{mol} / \mathrm{m}^{2} / \mathrm{s}$, when the plants in the model example were able to reduce the requirement for the amount of supplied air by 2.00 .

Figs. 1-4 clearly show the results of modeling the indoor environment according to the required quality of the IDA indoor environment, according to lighting and according to the implementation of plants. In each case, when plants were implemented in the indoor environment, a reduction in the requirement for the total amount of air supplied to the model space was achieved. In Figs. 1-4, the savings are marked with a '-' sign.
The most significant reduction in demand on the amount of supplied air was found in the case of operation of environments with poorer quality of indoor environment IDA4+, where $1 \mathrm{~m}^{2}$ of green plant per person was able to reduce the requirement for the amount of supply air by $1.997 \%$ for PPFD $200 \mu \mathrm{mol} / \mathrm{m}^{2} / \mathrm{s}$, and $0.218 \%$ for PPFD $50 \mu \mathrm{mol} / \mathrm{m}^{2} / \mathrm{s}$.

The implementation of plants in the IDA4 environment has the effect of reducing the amount of supplied air by $1.632 \%$ for PPFD $200 \mu \mathrm{mol} / \mathrm{m}^{2} / \mathrm{s}$ and $0.177 \%$ for PPFD $50 \mu \mathrm{mol} / \mathrm{m}^{2} / \mathrm{s}$, and in the case of IDA3, by 1.228 $\%$ for PPFD $200 \mu \mathrm{mol} / \mathrm{m}^{2} / \mathrm{s}$ and $0.133 \%$ for PPFD 50 $\mu \mathrm{mol} / \mathrm{m}^{2} / \mathrm{s}$. It can be assumed that savings could be further optimized by using modern control systems, such as Smart Optimum and Decision Intelligent Control, or by using systems based on data collection into

Fig. 1. Total comparison of the amount of supplied air and the potential for savings in the case of placing plants in the model space depending on PPFD and class IDA2

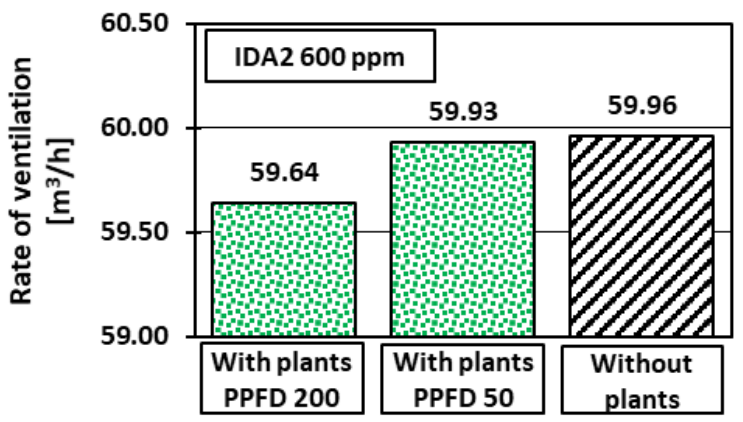

\section{Without plants:}

$\mathrm{Q}_{\text {sup } 1}=59.96 \mathrm{~m}^{3} / \mathrm{h}$;

With plants and PPFD $50\left[\mu \mathrm{mol} / \mathrm{m}^{2} / \mathrm{s}\right]$ :

$\mathrm{Q}_{\text {sup2 }}=59.93 \mathrm{~m}^{3} / \mathrm{h}$; Difference: $-0.058 \%$

With plants and PPFD $200\left[\mu \mathrm{mol} / \mathrm{m}^{2} / \mathrm{s}\right]$ :

$\mathrm{Q}_{\text {sup } 3}=59.64 \mathrm{~m}^{3} / \mathrm{h}$; Difference: $-0.537 \%$

Fig. 2. Total comparison of the amount of supplied air and the potential for savings in the case of placing plants in the model space depending on PPFD and class IDA3

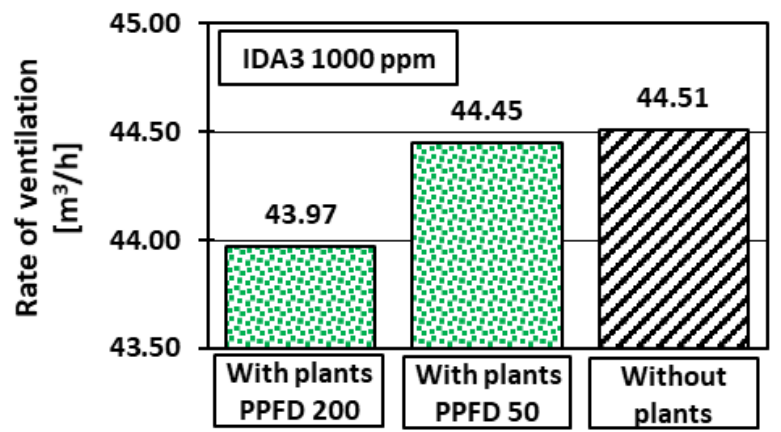

Without plants:

$\mathrm{Q}_{\text {sup } 1}=44.51 \mathrm{~m}^{3} / \mathrm{h}$;

With plants and PPFD $50\left[\mu \mathrm{mol} / \mathrm{m}^{2} / \mathrm{s}\right]$ : $\mathrm{Q}_{\text {sup } 2}=44.45 \mathrm{~m}^{3} / \mathrm{h}$; Difference: $-0.133 \%$

With plants and PPFD $200\left[\mu \mathrm{mol} / \mathrm{m}^{2} / \mathrm{s}\right]$ :

$Q_{\text {sup3 }}=43.97 \mathrm{~m}^{3} / \mathrm{h}$; Difference: $-\mathbf{1 . 2 2 8 \%}$ 
Fig. 3. Total comparison of the amount of supplied air and the potential for savings in the case of placing plants in the model space depending on PPFD and class IDA4

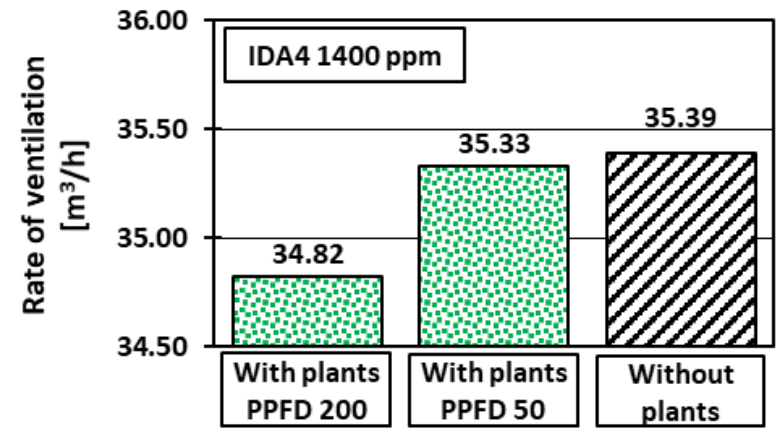

\section{Without plants: \\ $\mathrm{Q}_{\text {sup } 1}=35.39 \mathrm{~m}^{3} / \mathrm{h}$;}

With plants and PPFD $50\left[\mu \mathrm{mol} / \mathrm{m}^{2} / \mathrm{s}\right]$ : $\mathrm{Q}_{\text {sup } 2}=35.33 \mathrm{~m}^{3} / \mathrm{h}$; Difference: $-0.177 \%$

With plants and PPFD $200\left[\mu \mathrm{mol} / \mathrm{m}^{2} / \mathrm{s}\right]$ : $\mathrm{Q}_{\text {sup } 3}=34.82 \mathrm{~m}^{3} / \mathrm{h}$; Difference: $\mathbf{- 1 . 6 3 2 \%}$

Fig. 4. Total comparison of the amount of supplied air and the potential for savings in the case of placing plants in the model space depending on PPFD and class IDA4+

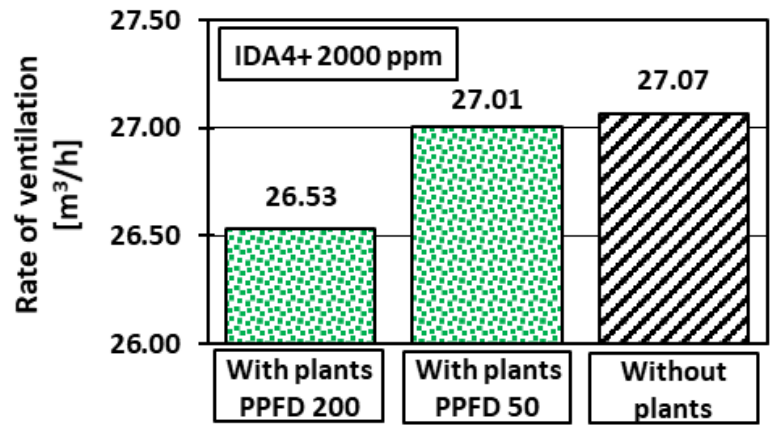

\section{Without plants:}

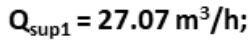

With plants and PPFD $50\left[\mu \mathrm{mol} / \mathrm{m}^{2} / \mathrm{s}\right]$ :

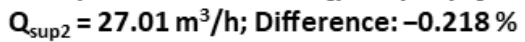

With plants and PPFD $200\left[\mu \mathrm{mol} / \mathrm{m}^{2} / \mathrm{s}\right]$ : $\mathrm{Q}_{\text {sup } 3}=26.53 \mathrm{~m}^{3} / \mathrm{h}$; Difference: $-1.997 \%$ cloud storage, their current analysis and immediate application to automatic internal control of building environment (Yao \& Zheng, 2010; Yang et al., 2019). With the help of intelligent automatic control systems, it is then possible to optimize the layout of the furniture in the indoor environment and the immediate requirements of users for the quality of the indoor environment (Hormigos-Jimenez et al., 2018; Majewski et al., 2020).

The results show that plants have the greatest impact in environments that have less demand for the amount of changed air. It should be noted that the highest plant efficiency is recorded for IDA4+, where approximately half the level of ventilation is expected compared with the IDA2 environment.

\section{Conclusions}

The presented research theoretically proves that plants have the potential to reduce the concentration of $\mathrm{CO}_{2}$ in the indoor environment and thus result in operational savings on ventilation and air-condition of buildings while maintaining the same quality parameters. The most significant savings are achieved in areas with poorer quality of the indoor environment, where a high degree of ventilation is not expected; in such an environment, research has shown the potential for operational savings in the field of ventilation of intelligent buildings to be up to $1.997 \%$. On the contrary, the smallest potential in the model environment has the implementation of the same area of plants in an environment where 
intensive ventilation is expected due to the high quality of the environment; here, theoretically, savings only between $0.058 \%$ and $0.537 \%$ were demonstrated. To increase the potential plant implementation even in intensively ventilated areas, it is necessary to significantly increase the total area of implemented greenery.

From the economical point of view of building's operation, the influence of plants with the level of PPFD 50 $\mu \mathrm{mol} / \mathrm{m}^{2} / \mathrm{s}$ and at actual concentration of $\mathrm{CO}_{2}$ in indoor supply air with $410 \mathrm{ppm}$ is neglected for all researched classes of IDA. Potentially measurable savings in practice in the amount of reduced ventilated air can be seen

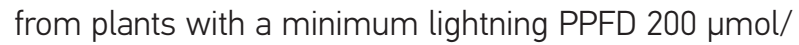
$\mathrm{m}^{2} / \mathrm{s}$. For overall economic profitability assessment, it is necessary to realize further research, which takes into account a possible operation of a lighting system and plant maintenance in the indoor environment.

Research has shown a positive potential of plants for indoor environmental quality. The model considered the

\section{References}

Allen, J., MacNaughton, P., Satish, U., Santanam, S., Vallarino, J., and Spengler, J. (2016). Associations of Cognitive Function Scores with Carbon Dioxide, Ventilation, and Volatile Organic Compound Exposures in Office Workers: A Controlled Exposure Study of Green and Conventional Office Environments. Environmental Health Perspectives, 124(6), 805-812. https://doi.org/10.1289/ehp.1510037

Aryal, P., and Leephakpreeda, T. (2015). CFD Analysis on Thermal Comfort and Energy Consumption Effected by Partitions in Air-Conditioned Building. In Energy Procedia (vol. 79, pp. 183188). https://doi.org/10.1016/j.egypro.2015.11.459

Buratti, C., Palladino, D., and Moretti, E. (2017). Prediction Of Indoor Conditions And Thermal Comfort Using CFD Simulations: A Case Study Based On Experimental Data. In Energy Procedia (vol. 126, pp. 115-122). https://doi.org/10.1016/j.egypro.2017.08.130

Field, C., Barros, V., Dokken, D., Mach, K., and Mastrandrea, M. (2014). Human Health: Impacts, Adaptation, and Co-Benefits. Climate Change 2014 Impacts, Adaptation, and Vulnerability, 709-754. https://doi.org/10.1017/CB09781107415379.016

Franek, O., Kravcov, A., and Jarský, Č. (2020). New Experimental Method for Pollutants Elimination. In GEOLINKS 2020 International Scientific Conference: GREEN BUILDINGS TECHNOLOGIES AND MATERIALS Section (pp. -). https://doi.org/10.32008/ GEOLINKS2020/B2/V2/25
$\mathrm{CO}_{2}$ concentration of the air supply from outside to be 410 ppm. Assuming that the concentration of $\mathrm{CO}_{2}$ in the outside air continues to increase over the next century, the implementation of plants in the indoor environment of buildings will be far more important and the savings achieved on ventilation of intelligent buildings with such increased $\mathrm{CO}_{2}$ concentration will be greater.

The present research shows a completely new perspective on the issue of energy saving ventilation in intelligent buildings, which is appropriate to pay attention to and further investigate.

\section{Acknowledgements}

The authors are grateful to the Czech Technical University in Prague. The present research was supported by the grant SGS21/007/OHK1/1T/11, Czech Technical University in Prague.

Gubb, C., Blanusa, T., Griffiths, A., and Pfrang, C. (2018). Can houseplants improve indoor air quality by removing $\mathrm{CO} 2$ and increasing relative humidity?, 11(10), 1191-1201. https://doi. org/10.1007/s11869-018-0618-9

Hersoug, L., Sjödin, A., and Astrup, A. (2012). A proposed potential role for increasing atmospheric $\mathrm{CO} 2$ as a promoter of weight gain and obesity. Nutrition and Diabetes, 2(3), e31-e31. https://doi.org/10.1038/nutd.2012.2

Hormigos-Jimenez, S., Padilla-Marcos, M., Meiss, A., Gonzalez-Lezcano, R., and Feijó-MuÑoz, J. (2018). Experimental validation of the age-of-the-air CFD analysis: A case study. Science and Technology for the Built Environment, 24(9), 994-1003. https://doi.org/10.1080/23744731.2018.1444885

Hormigos-Jimenez, S., Padilla-Marcos, M., Meiss, A., Gonzalez-Lezcano, R., and Feijó-Muñoz, J. (2018). Computational fluid dynamics evaluation of the furniture arrangement for ventilation efficiency. Building Services Engineering Research and Technology, 39(5), 557-571. https://doi.org/10.1177/0143624418759783

Chan, W., Li, X., Singer, B., Pistochini, T., Vernon, D., Outcault, S., Sanguinetti, A., and Modera, M. (2020). Ventilation rates in California classrooms: Why many recent HVAC retrofits are not delivering sufficient ventilation. Building and Environment, 167. https://doi.org/10.1016/j.buildenv.2019.106426 
Irga, P., Pettit, T., Irga, R., Paull, N., Douglas, A., and Torpy, F. (2019). Does plant species selection in functional active green walls influence VOC phytoremediation efficiency?. Environmental Science and Pollution Research, 26(13), 12851-12858. https://doi.org/10.1007/s11356-019-04719-9

Liu, J., Heidarinejad, M., Nikkho, S., Mattise, N., and Srebric, J. (2019). Quantifying Impacts of Urban Microclimate on a Building Energy Consumption-A Case Study. Sustainability, 11(18). https://doi.org/10.3390/su11184921

Lu, C., Lin, J., Chen, Y., and Chen, Y. (2015). Building-Related Symptoms among Office Employees Associated with Indoor Carbon Dioxide and Total Volatile Organic Compounds. International Journal of Environmental Research and Public Health, 12(6), 5833-5845. https://doi.org/10.3390/ijerph120605833

Majewski, G., Orman, Ł., Telejko, M., Radek, N., Pietraszek, J., and Dudek, A. (2020). Assessment of Thermal Comfort in the Intelligent Buildings in View of Providing High Quality Indoor Environment. Energies, 13(8). https://doi.org/10.3390/en13081973

McNeil, B., and Sasse, T. (2016). Future ocean hypercapnia driven by anthropogenic amplification of the natural $\mathrm{CO} 2$ cycle. Nature, 529(7586), 383-386. https://doi.org/10.1038/nature16156 Nelson, J., Bugbee, B., and Campbell, D. (2014). Economic Analysis of Greenhouse Lighting: Light Emitting Diodes vs. High Intensity Discharge Fixtures. PLoS ONE, 9(6). https://doi. org/10.1371/journal.pone.0099010

Pennisi, S., and van lersel, M. (2012). Quantification of Carbon Assimilation of Plants in Simulated and In Situ Interiorscapes. HortScience, 47(4), 468-476. https://doi.org/10.21273/HORTSCl.47.4.468

Persily, A., and de Jonge, L. (2017). Carbon dioxide generation rates for building occupants. Indoor Air, 27(5), 868-879. https:// doi.org/10.1111/ina.12383

Pettit, T., Irga, P., Abdo, P., and Torpy, F. (2017). Do the plants in functional green walls contribute to their ability to filter particulate matter?. Building and Environment, 125, 299-307. https:// doi.org/10.1016/j.buildenv.2017.09.004

Pinto, M., Lanzinha, J., Viegas, J., Infante, A., and Freire, T. (2021). Kindergartens and nurseries in central portugal. assessments of indoor environment quality. International Journal of Sustainable Building Technology and Urban Development, 12(1), 27-43. https://doi.org/10.22712/susb.20210004

Satish, U., Mendell, M., Shekhar, K., Hotchi, T., Sullivan, D., Streufert, S., and Fisk, W. (2012). Is CO 2 an Indoor Pollutant? Direct Effects of Low-to-Moderate CO 2 Concentrations on Human
Decision-Making Performance. Environmental Health Perspectives, 120(12), 1671-1677. https://doi.org/10.1289/ehp.1104789

Seppanen, O., Fisk, W., and Mendell, M. (1999). Association of Ventilation Rates and $\mathrm{CO} 2$ Concentrations with Health and Other Responses in Commercial and Institutional Buildings. Indoor Air, 9(4), 226-252. https://doi.org/10.1111/j.1600-0668.1999.00003.x

Serrano, S., Ürge-Vorsatz, D., Barreneche, C., Palacios, A., and Cabeza, L. (2017). Heating and cooling energy trends and drivers in Europe. Energy, 119, 425-434. https://doi.org/10.1016/j. energy.2016.12.080

Shao, Y., Li, J., Zhou, Z., Hu, Z., Zhang, F., Cui, Y., and Chen, H. (2021). The effects of vertical farming on indoor carbon dioxide concentration and fresh air energy consumption in office buildings. Building and Environment, 195. https://doi.org/10.1016/j. buildenv.2021.107766

Torpy, F., Zavattaro, M., and Irga, P. (2017). Green wall technology for the phytoremediation of indoor air: a system for the reduction of high CO2 concentrations, 10(5), 575-585. https://doi. org/10.1007/s11869-016-0452-x

Tsai, D., Lin, J., and Chan, C. (2012). Office Workers' Sick Building Syndrome and Indoor Carbon Dioxide Concentrations. Journal of Occupational and Environmental Hygiene, 9(5), 345-351. https://doi.org/10.1080/15459624.2012.675291

Tudiwer, D., and Korjenic, A. (2017). The effect of an indoor living wall system on humidity, mould spores and CO 2 -concentration. Energy and Buildings, 146, 73-86. https://doi. org/10.1016/j.enbuild.2017.04.048

Tuháček, M., Franek, O., and Svoboda, P. (2020). Application of FMEA methodology for checking of construction's project documentation and determination of the most risk areas. Acta Polytechnica, 60(5), 448-454. https://doi.org/10.14311/ AP.2020.60.0448

Ürge-Vorsatz, D., Cabeza, L., Serrano, S., Barreneche, C., and Petrichenko, K. (2015). Heating and cooling energy trends and drivers in buildings. Renewable and Sustainable Energy Reviews, 41, 85-98. https://doi.org/10.1016/j.rser.2014.08.039

Yang, C., Chen, S., Den, W., Wang, Y., and Kristiani, E. (2019). Implementation of an Intelligent Indoor Environmental Monitoring and management system in cloud. Future Generation Computer Systems, 96, 731-749. https://doi.org/10.1016/j.future.2018.02.041

Yao, R., and Zheng, J. (2010). A model of intelligent building energy management for the indoor environment. Intelligent Buildings International, 2(1), 72-80. https://doi.org/10.3763/ inbi.2009.0033 